УДК 778.534.66 : $778.534 .4(476)$

Антонина Алексеевна Карпилова,

кандидат искусствоведения, доцент, заведующий отделом экранных искусств, Центр исследований белорусской культуры, языка и литературы,

Национальная академия наук Беларуси, Минск, Беларусь

\title{
ЗВУКОВОЕ РЕШЕНИЕ АНИМАЦИОННОГО ФИЛЬМА В КИНЕМАТОГРАФЕ БЕЛАРУСИ
}

Аннотация. В статье рассматривается звуковое решение анимационного фильма, которое понимается как особый способ построения звукового ряда фильма в его соотношении с визуальным рядом и общей драматургией произведения. Звуковое решение фильма включает в себя такие компоненты, как речь, музыка и шумы в акустически пространственном и образном соотношении и предполагает осмысление функционирования музыки, шумов и речи в контексте образной системы кинопроизведения. Звуковое решение как составляющая образносемантической структуры анимационного фильма имеет особые средства выразительности (интонация, ритм, тембр и др.) и способы отражения действительности (ассоциативное отражение предметного мира, идей, эмоций), что позволяет ей служить специфическим авторским способом создания художественного экранного образа языком звуковой экспрессии. Выделены специфические особенности звуковых компонентов в контексте анимационного фильма: речи как наиболее реального и одновременно условного звукового компонента, музыки как самого эмоционального элемента, искусственное происхождение и тембровая необычность шумовой партитуры. На основе анализа звукового решения лучших белорусских анимационных фильмов режиссеров Игоря Волчека, Елены и Владимира Петкевич, Ирины 
Кодюковой делается вывод о том, что звуковое решение выступает в них как важный содержательный и формообразующий компонент, посредством которого осуществляется авторский замысел. В анимационном фильме звук играет значительную роль как общепонятный язык, который может косвенно пояснять сюжет, рассказывать об исторических и социальных явлениях, иллюстрировать внутренние чувства и историю персонажей. Этими свойствами анимации обусловлено ее активное внедрение в игровое кино, видеоклипы, рекламу. Место анимационного кино в современной художественной культуре позволяет предполагать широкие перспективы ее развития в качестве одного из важных средств массовой коммуникации.

Ключевые слова: звуковое решение фильма, анимационное кино, киномузыка, речевые и шумовые компоненты фильма.

Введение. Анимационное кино как вид неигрового киноискусства в силу своих технических особенностей и художественных возможностей эстетического освоения мира стремительно развивается и требует современного теоретического осмысления. Развитие анимационного кино ставит в числе других вопрос звукового решения фильма, которое понимается как особый способ построения звукового ряда фильма в его соотношении с визуальным рядом и общей драматургией произведения. Звуковое решение фильма включает в себя такие компоненты, как речь, музыка и шумы в акустически пространственном и образном соотношении и предполагает осмысление функционирования звуковых компонентов в контексте художественного единства экранного произведения.

Постановка проблемы. Обозначенный аспект приобретает особую актуальность в связи с расширением процессов сквозного взаимодействия визуальной и звуковой сторон в современной анимации. Влияние звукового решения 
распространяется как на композиционно-драматургическую организацию анимационных фильмов, так и на создание новых анимационных жанров. Звуковое решение фильма активно участвует в создании художественного образа на всех структурных уровнях экранного произведения: звукозрительном, фабульно-сюжетном, композиционно-образном, концепционном.

Актуальность изучения звукового решения анимационного фильма связана с потребностью в методологической разработке основ звукового решения анимационного фильма и теоретического обобщения практического опыта в области национального анимационного кино.

\section{Анализ последних исследований и публикаций.}

Теоретическому осмыслению звукового решения анимационных произведений посвящены отдельные работы. В частности, польский исследователь 3. Лисса справедливо отмечает, что мультфильм «представляет мир фантастический, где принципиально возможны все виды связей зрительного и звукового элемента» [3, с. 398], где открывается широкое поле для экспериментов в области связей между обеими сферами. В монографии Т. Шак «Музыка в структуре медиатекста. На материале художественного и анимационного кино» рассматриваются основные принципы музыкальной драматургии анимационного фильма и разработана авторская методика анализа музыкального решения мультфильма [4]. В работе И. Бегизовой «Взаимодействие музыки и изображения в образной структуре мультипликационного фильма» обозначены основные функции музыки и принципы визуальной интерпретации музыки в мультипликационном кино [1].

Более широкой проблематике не только музыкального, но и звукового решения фильма посвящена работа Гвон Гюн Гжа «Художественно-эстетическая специфика звука в анимационном кино», где рассматриваются звуковые эффекты, пространственновременные особенности звука в анимации, звуковая драматургия анимационного фильма и т. д. Автор отмечает, что 
пространственно-временная природа анимационного фильма, его технические и эстетические инновации, а также специфика системно-структурной и композиционно-драматургической организации обуславливают его возможность адаптировать и творчески трансформировать в художественной структуре фильма формы, жанры и средства звуковой выразительности, что подтверждается целостным анализом авторских фильмов Ю. Норштейна [2].

Анализ теоретических источников убеждает в том, что в настоящее время не существует целостной концепции звукового решения анимационного фильма, обусловленной взаимодействием всех звуковых компонентов в структуре экранного произведения.

В свете вышесказанного целью настоящей статьи является выявление особенностей звукового решения в белорусских анимационных фильмах и определение значения звукового компонента в создании художественного единства произведения.

Изложение основного материала. Вначале определим специфические особенности звуковых компонентов в контексте анимационного фильма. Так, речь в анимации «является, пожалуй, самым реальным элементом, способным усиливать его “жизнеподобие”» $[1$, с. 52], но остается одним из важнейших носителей содержания. Зачастую в анимации используется преображенное и трансформированное звучание голосов, что служит целям создания необычной речи и артикуляции условных анимационных персонажей.

Музыка в анимации играет огромную роль и иногда выступает единственной частью фонограммы, поскольку является таким же условным искусством, как и анимация - здесь совпадают онтологические и гносеологические основы обоих видов искусства. Музыка может быть написана специально для мультфильма (оригинальная музыка) или строиться на цитатах (компилятивная музыка); эти два способа могут также сочетаться в одном мультфильме. Функции музыки связаны с eе 
возможностью создавать эмоциональную атмосферу, передавать чувства персонажей, характеризовать время и место действия, когда востребованными становятся ее тембровые, мелодикоритмические, жанровые и др. особенности.

Шумы и звуковые эффекты в анимационных фильмах отличаются своей необычностью, в основном иллюстрируют и акцентируют движения или действия персонажей, их трансформацию, пространственно-временные изменения, смену кадров, смысловые переходы и т. д. Придуманные, генерированные шумы вполне соответствуют искусственно созданной среде анимационного фильма, в которой существуют невероятные персонажи.

Белорусская анимация начала активно развиваться только с 1970-х гг., но путь почти в половину столетия стал плодотворным для национальной анимации, которая существует в основном на базе Национальной киностудии «Беларусьфильм». С полной уверенностью можно говорить о появлении и эволюции в белорусской анимации авторского анимационного кино, трансформации художественного языка и жанровых форм, реализации новых технических возможностей.

С самого начала белорусского анимационного кино одним из главных стал вопрос кинозвука, который делает искусственный мир анимации более реальным, «оживляет» изобразительный ряд, тонко воздействует на восприятие зрителя и создает нужное настроение. Однако путь к постижению тайн звукозрительного синтеза был сложным и многотрудным.

В раннем периоде развития белорусской анимации (1973 1985 гг.) в фильмах доминировали иллюстративная музыка, внутрикадровая речь, минимальное количество шумов. Режиссер обычно следовал за словесным рядом, изображение строилось по принципу «прорисовки слова», а звуковой элемент понимался как иллюстративно-конструктивный. Этапным в понимании анимационного звука стал фильм «Песня о Зубре» (1982 г., режиссер Олег Белоусов, композитор Леонид Захлевный, 
звукорежиссер Борис Шангин), где авторы создали многослойную звуковую партитуру, которая является непревзойденной в белорусской анимации по определенным параметрам: по богатству интонационно-тематических и тембровых источников, отсылающих к музыкально-звуковым архетипам национальной культуры; по органичному соединению в единое целое всех компонентов фоносферы - речи (поэму Николая Гусовского читает актер Виктор Тарасов), музыки и шумов. Среди звуковых архетипов выделяются народные наигрыши, сигналы охоты, колокольный звон. Звуковое решение вслед за визуальным рядом направлено на воплощение идей диалога человека с миром, с природой, осмысление первоистоков белорусского этноса. В звуке соединены эпическое и лирическое, объективное и субъективное начала. Самый яркий и захватывающий эпизод фильма - сцена охоты, где звучат необычный тембр рога и музыкальная тема гимнического характера, которая рисует звуковой образ человека как части природы. Звуковая партитура насыщена звучанием народных инструментов (белорусской дудки, жалейки), колокола как духовного символа, криков ворона в виде предвестника несчастья, рыка зубра как властелина белорусской природы. После эпизода войны и звукового хаоса, где смешаны песенные фразы, человеческий крик и звериный вой, наступает финальный апофеоз: женское соло воспринимается как голос Богородицы, несущий мир и гармонию.

Настоящий прорыв в звуковом пространстве белорусского анимационного кино начался с 1986 г., что было связано с появлением и активным развитием авторского фильма. Точкой отсчета стали два фильма, которые стали классикой не только белорусского, но и европейского анимационного кино, получив множество наград на зарубежных конкурсах и фестивалях. Именно в них были обозначены основные векторы звукового решения белорусских анимационных фильмов, которые продолжают развиваться в настоящее время. 
Уникальная в своем роде фоносфера была создана в ленте «Лафертовская маковница» (1986 г., режиссер Елена МарченкоПеткевич, композитор Олег Оловников, звукорежиссер Сергей Чупров), снятой по мотивам одноименной повести Антония Погорельского и исполненной в оригинальной технике песка. Лейттембром фильма, рассказывающего трогательную сказку о девочке-сироте, стало звучание виолончели - солирующее или погруженное в многоголосную звуковую партитуру. В тонко разработанной речевой области присутствуют четыре темы: акустически искаженной и неестественной голосовой сфере Мачехи противостоят темы Девочки-рассказчицы, Бабушки и Кота. Хрупкому тембру детского голоса контрастирует зловещий, гипертрофированный реверберацией голос Мачехи. Шумовая сфера представлена имитационными электронными звуками, среди которых крик сороки, вой ветра, падающие капли, неразборчивый шепот. Под хрустальный звон колокольчиков бабушка, которая сидит на облаке, сыплет маленькие маковые зерна, похожие на звезды, а они превращаются в символы детской памяти - деревья, мельницу, дом. Прием многослойности звуковой композиции выдерживается на протяжении всего повествования, составляя двухслойную (соединение речи и музыки, музыки и шумов, шумов и речи) и трехслойную структуру (соединение всех звуковых компонентов) фоносферы. «Тихой» кульминацией фильма становится молитва бабушки: «В нужде беспокойной, во тревоге и горести не остави нас, день ясноокий, сохрани нас, ночь темная, укрой любовью земной всякого малого, всякого беззащитного». Идея фильма выражена в авторском тексте: «Я хотела бы сходить за сокровищами... Не бежать от своего детства, а идти ему навстречу; любить и видеть то, что нельзя тронуть рукой: лес, воздух, тишину, небо, луну, время». Так принцип «драматургии памяти», воплощенный в структуре знаменитого фильма «Сказка сказок» Ю. Норштейна, нашел свое продолжение в ленте его ученицы и последовательницы. 
Фильм-притча «Каприччио» (1986 г., режиссер Игорь Волчек, звукорежиссер Сергей Чупров) стал настоящим событием для белорусского кино. Лента, своим названием отсылающая к музыкальной форме импровизационной структуры, явилась своеобразным лирическим эссе на тему взросления и ответственности перед собой. Жизнь человека проходит в дороге, в неуютном жестком вагоне. Через весь фильм проходит звуковой образ неумолимо идущего времени - стук колес и звук капель воды, падающих в дрожащий от движения вагона стакан. Вцелом они напоминают звук метронома и ассоциируются с темой стремительно проносящейся жизни. Спасительными островками в памяти героя становятся музыкальные фрагменты: воспоминания о большом черном рояле, за которым мальчик играет «К Элизе» Л. Бетховена, звучание песни «Мишель» ансамбля «Битлз», хора «Gaudeamus». Драматургически активно, на уровне авторской концепции использованы образно-смысловые возможности музыкальных цитат. Ученическая гамма или чувствительное танго воспринимаются как символы определенных этапов жизни герояавтора.

Впоследствии доминирование музыкального компонента в звуковом решении фильма проявилось в анимационной притче режиссера Владимира Петкевича «Месяц» (1993 г., композитор Виктор Копытько, звукорежиссер Владимир Головницкий). В основе фильма лежит морально-нравственная оппозиция, представленная жизнью и деяниями двух братьев, один из которых олицетворяет добро, а другой подчиняется сказочному антигерою Цмоку и является символом зла. Звуковые характеристики братьев построены на интонациях песен, созданных композитором в духе народных белорусских песен, «Уставала, кашулю вышывала» и «Хай вам ад сонейка цёпленька будзе». Тема брата-музыканта представляет собой терцовую мажоро-минорную попевку в прямом движении, а тема злого брата - инверсию этой попевки. На протяжении картины две музыкальные темы находятся в постоянном противодействии. 
Сферу добра воплощают также светлые образы народных песен и детской считалки, природные шумы. Сферу зла несут звукошумовая фактура, представляющая нарочито фальшивые мелодические попевки; неясные синтезированные созвучия в низком регистре; причудливые, измененные до неузнаваемости шумы. Контраст и столкновение образных сфер позволяют говорить о конфликтном типе звуковой драматургии в фильме.

Полифоническая структура и семантическая насыщенность звукового поля существуют и в ленте Владимира Петкевича «Жило-было дерево...» (1996 г., композитор Виктор Копытько, звукорежиссер Владимир Головницкий). Анимационная притча о гармоничности бытия, единства человека и природы, о сущностных и вечных вещах стала самым светлым и, пожалуй, самым личностным фильмом режиссера, где доминируют теплые краски, легкий штриховой рисунок, изящество и легкость линий. Такой изобразительной стилистике соответствует прозрачная по фактуре, «легкая» по тембровым параметрам партитура, в которой есть своя драматургия, неразрывно связанная с общей драматургией ленты. Этот удивительно гармоничный по мировосприятию фильм обращен к архетипическим образам белорусской культуры. Рефреном стала наивно-трогательная музыкальная тема времени, которая существует наравне с естественными звуками жизни - смехом девочки, мычанием коровы, щебетом птиц, блеянием овец, - и несет смысл единства всего сущего. Замечательна сцена превращения девочки в птичку, которая со смехом прилетает к кормушке. Подобный прием пластических метаморфоз был продолжен композитором в музыкальной сфере. Основной теме контрастирует, но не противостоит более подвижная тема трехголосного фугато, с тембрами деревянных духовых, с острыми штрихами - она сопровождает жанровые зарисовки картин весенней, летней, осенней и зимней жизни старой яблони и обитателей маленького деревенского дома. Из невнятного гула постепенно прорастает мощное и ликующее звучание 
инструментального гимна в духе Антонио Вивальди: повзрослевшая девочка уходит из родного гнезда. Музыка сопровождает уход старика, который закрывает глаза, уходя навеки в иной мир, а яблоня, со стоном оторвавшись от земли, взлетает в небо. Уходит и старуха, прижав к себе кота. Но в финале возвращается радость - в заснеженной кормушке сидит синичка, она превращается в девочку и со смехом улетает. Слово присутствует в фоносфере ленты в минимальной степени, в тексте песни «Яблыня 3 лістом» (текст народный, музыка Виктора Копытько), которая звучит в ключевых моментах фильма: в экспозиции, возникая из неясного гула, в кульминации (соло песни как образ опустевшего пространства после ухода девочки) и в сцене смерти старика. Шумовая фоносфера фильма богата и разнообразна, например, осенняя картина представлена выразительными звуковизуальными штрихами - стуком молотков и чириканьем воробьев, нахохлившихся на краю бочки с водой. Вой волков, треск сучьев и недифференцированный гул иллюстрирует одиночество стариков, оставшихся в избе. Ничего подобного этой анимационной притче, где ненавязчиво и легко, с любовью и юмором рассказано о вечных темах, в белорусской анимации не было. Здесь как бы материализовалось гомогенное поле сознания, где все равноценно, все переходит во все. Звуковая сфера строится из микротем, которые словно переходят в изображение и обратно, совмещая принцип взаимозаменяемости элементов в создании аудиовизуальной образности.

Основные тенденции эволюции кинозвука соединились в творчестве режиссера Ирины Кодюковой. Анимационный фильм «Удивительный ужин в Сочельник» (1999г., Звукорежиссер Андрей Волков) из цикла «Святочные рассказы» примечателен развернутой звуковой партитурой с оригинальной системой музыкальных лейтмотивов, натуральных шумов и звуковых эффектов. В сцене предрождественского вечера, на фоне светящихся окон многоэтажных домов слышны разнообразные звуки, создающие многослойную звуковую партитуру: это 
мелодия флейты и шум аэропорта, звуки городского транспорта и звонки в дверь, телефонные гудки и песня Владимира Высоцкого «Ну, здравствуй, это я!», рождественская молитва и колокол, зовущий к Всенощной. Все эти звучания разного происхождения природного, урбанистического, антропологического - не имеют визуальной поддержки в виде изобразительной иллюстрации, однако по принципу ассоциации создают целостный образ поэтичного, очень личностного фильма. Звуковой ряд предстает в виде авторского комментария, который компенсирует отсутствие адекватного изображения. Появление котов - главных героев удивительного ужина - отмечено «сказочным» звучанием арфы. Интонационные характеристики персонажей поражают своим разнообразием: у мамы мягкий и нежный голос, у хозяйки породистого кота - резкий и пронзительный; просительномяукающие звуки издают бездомные коты, а главный кот-бомж, увидев лужу сметаны, сипло произносит: «Ну, вы даете!» Так бытовыми приметами и юмористическими деталями обозначено наступление волшебного праздника.

В основе звукового решения кинопритчи «Легенда о леди Годиве» (2004 г., режиссер Ирина Кодюкова, звукорежиссер Андрей Волков) лежит песня московской певицы Елены Фроловой «Я вышла замуж в январе» на стихи Иосифа Бродского. Центральной музыкальной характеристикой главной героини, олицетворением еe чистоты, хрупкости и преданности своему народу стал вокализ, построенный на теме песни в сопровождении флейты и гитары. Музыкальная характеристика грозного мужа леди Годивы представляет собой шумовую фактуру, тематически неопределенную, несущую негативное эмоциональное состояние. В конце ленты народное гулянье сопровождается незамысловатым аккомпанементом гуслей и бубна.

Сочетание звуковых компонентов в фильме может быть различным. Сохранение всех неизменных звуковых характеристик персонажей, находящихся в кадре, содействует созданию 
дисгармонии. Музыкальное сопровождение (без шумов и речи) служит для дополнительного объяснения ситуации, уточнения эмоционального состояния, характера и действия героев. Отказ от музыки, но активное использование речи и шумов также возможно. Большую роль могут выполнять паузы и молчание, так как сама реальность является звучащей, абсолютной тишины не существует.

Например, в фильме «Марк Шагал. Начало» (2016 г., режиссер Елена Петкевич, композитор Софья Петкевич, звукорежиссер Владимир Суходолов) существует звуковая полифункциональность, царит яркая звуковая стихия, близкая карнавальной. Насыщенную звуковую сферу картины трудно раскладывать на компоненты, в ней много фантастических, генерированных звуков. И в то же время много звуковой «натуры» - это гудки пароходов и паровозов, лай собак и мычание коровы, жужжание насекомых и кваканье лягушек, но главное - звуки уютного родного дома. Синтез изображения и звука порой достигает мощной силы. Тиканье домашних часов и соловьиное пение постепенно сменяются воем ветра и зимней вьюги. Юный Шагал уходит в эту неведомую стихию, в революцию. Вместе с ним уходит целая эпоха и ее звучания. Многие музыкальные образы фильма с их танцевально-песенной архетипической основой будто отсылают к мифопоэтике Шагала, в картинах которого образ любимого Витебска приобрел библейский облик Иерусалима.

Процессы синтеза анимации и музыки способствуют созданию новых жанров белорусской анимации. Являясь общим знаменателем (композиционным, динамическим, эмоциональнопсихологическим, тематическим, темпо-ритмическим) для создания звукозрительной образности, музыкальная драматургия способствует развитию ассоциативно-образного языка анимационного кино. Так появился жанр белорусского анимационного мюзикла - лента «Звезды седьмого неба» (2020 г., режиссер Елена Турова, композитор Леонид Ширин), 
где персонажей озвучили звезды белорусской эстрады, театра и кино: Юрий Ващук, Денис Дудинский, Иван Вабищевич, Елена Дубровская, Светлана Залесская-Бень и др.

В целом звуковое решение как составная часть образносемантической структуры анимационного фильма имеет особые средства выразительности (интонация, ритм, тембр и др.) и способы отражения действительности (ассоциативное отражение предметного мира, идей, эмоций), что позволяет ей служить специфическим авторским способом создания художественного экранного образа.

Выводы. Достижения белорусского анимационного кино в области звуковой и звукозрительной образности связаны с авторским кинематографом и находятся в русле общих поисков мировой анимации. В лучших белорусских анимационных фильмах звуковой компонент выступает как важный содержательный и формообразующий фактор, посредством которого осуществляется авторский замысел. Звуковое решение анимационного фильма активно участвует в формировании экранного образа, выступает в художественном пространстве и времени фильма в диалектическом единстве содержательного и конструктивного начал.

В наиболее значительных белорусских анимационных лентах звуковая сфера многослойна и полифункциональна: она включает закадровую музыку, диктующую фильму ритм, а персонажам - характер движения; внутрикадровую музыку, перерастающую в визуальные символы; шумы, подчеркивающие ощущение реальности; речь персонажей и дикторский текст, которые являются конструктивным элементом и одновременно авторским комментарием с множественностью интонаций и функций.

В анимационном кино звук играет значительную роль как общепонятный язык, с помощью которого можно косвенно пояснять сюжет, рассказывать об исторических и социальных явлениях, иллюстрировать внутренние чувства и историю 
персонажей. Данными свойствами анимации обусловлено ее активное внедрение в игровое кино, видеоклипы, рекламу. Место анимации в современной художественной культуре позволяет предполагать широкие перспективы ее развития в качестве одного из средств массовой коммуникации.

\section{Литература}

1. Бегизова И. Взаимодействие музыки и изображения в образной структуре мультипликационного фильма: Автореф. дис. ... канд. искусствовед.: 17.00.03. Тбилиси: Тбилисская гос. консерватория имени В. Сараджишвили, 1985. 27 с.

2. Гвон Гюн Гжа. Художественно-эстетическая специфика звука в анимационном кино: Автореф. дис. ... канд. искусствовед.: 17.00.03. Москва: Всерос. гос. ин-т кинематографии им. С. А. Герасимова, 2005. 25 с.

3. Лисса 3. Эстетика киномузыки. Москва: Музыка, 1970. $495 \mathrm{c}$.

4. Шак T. Музыка в структуре медиатекста. На материале художественного и анимационного кино. Санкт-Петербург: Планета музыки, 2019. 384 с.

\section{Антоніна Олексіївна Карпілова,}

кандидат мистецтвознавства, доцент,

завідувач відділу екранних мистецтв,

Центр досліджень білоруської культури, мови та літератури,

Національна академія наук Білорусі,

Мінськ, Білорусь

\section{ЗВУКОВЕ РІШЕННЯ АНІМАЦІЙНОГО ФІЛЬМУ У КІНЕМАТОГРАФІ БІЛОРУСІ}

Анотація. У статті розглядається звукове рішення анімаційного фільму, яке розуміється як особливий спосіб побудови звукового ряду фільму в його співвідношенні 3 
візуальним рядом і загальною драматургією твору. Звукове рішення фільму включає в себе такі компоненти, як мова, музика i шуми в акустично просторовому й образному співвідношенні і передбачає осмислення функціонування музики, шумів і мови в контексті образної системи кінотвору. Звукове рішення як складова образно-семантичної структури анімаційного фільму має особливі засоби виразності (інтонація, ритм, тембр та ін.) і способи відображення дійсності (асоціативне відображення предметного світу, ідей, емоцій), що дозволяє їй служити специфічним авторським способом створення художнього екранного образу мовою звукової експресії. Виділені специфічні особливості звукових компонентів у контексті анімаційного фільму: мовлення як найреальнішого i одночасно умовного звукового компонента, музики як самого емоційного елемента, штучне походження і темброва незвичайність шумової партитури. На основі аналізу звукового рішення кращих білоруських анімаційних фільмів режисерів Ігоря Волчека, Олени та Володимира Петкевич, Ірини Кодюкової робиться висновок про те, що звукове рішення виступає в них як важливий змістовний i формотворчий компонент, за допомогою якого здійснюється авторський задум. В анімаційному фільмі звук відіграє значну роль як загальнозрозуміла мова, яка може побічно пояснювати сюжет, розповідати про історичні та соціальні явища, ілюструвати внутрішні почуття й історію персонажів. Цими властивостями анімації обумовлено іiі активне впровадження в ігрове кіно, відеокліпи, рекламу. Місце анімаційного кіно в сучасній художній культурі дозволяє припускати широкі перспективи іiі розвитку в якості одного з важливих засобів масової комунікації.

Ключові слова: звукове рішення фільму, анімаційне кіно, кіномузика, мовні та шумові компоненти фільму. 


\title{
Antonina O. Karpilova, \\ PhD in Arts, Associate Professor, Head of the Department of screen arts, \\ Center for research of Belarusian culture, language and literature, \\ National Academy of Sciences of Belarus \\ Minsk, Belarus \\ SOUND DESIGN OF AN ANIMATED FILM IN THE CINEMA OF BELARUS
}

\begin{abstract}
The article discusses the sound design of an animated film, which is understood as a special way of constructing the sound lines of a film in its ratio to the visual range and the overall dramaturgy of the work. The sound solution of the film includes such components as speech, music and noise in an acoustically spatial and figurative ratio and involves understanding the functioning of music, noise and speech in the context of a figurative system of the film. Sound solution as a component of the figurative-semantic structure of an animated film has special expressive means (intonation, rhythm, timbre, etc.) and ways of reflecting the reality (associative reflection of the objective world, ideas, emotions), which allows it to serve as a specific author's way of creating an artistic screen image with the language of sound expression. The specific features of sound components in the context of an animated film are highlighted: speech as the most real and at the same time symbolic sound component, music as the most emotional element, artificial origin and timbre unusual of the noise score. Based on the analysis of the sound solution of the best Belarusian animated films directed by Igor Volchek, Elena and Vladimir Petkevich, Irina Kodyukova, it is concluded that the sound solution appears in works as an important substantive and formative component and by this the author's intention is realized. In an animated film, sound plays a significant role as a common language that can indirectly explain the plot, talk about historical and social phenomena, illustrate the inner feelings and history of the characters.
\end{abstract}


Due to these properties animation is extensively implemented in feature films, video clips, and advertising. The place of animated cinema in contemporary artistic culture allows us to assume broad prospects for its development as one of the important mass communication medium.

Key words: sound design of the film, animated film, film music, speech and noise components of the film.

\section{References}

1. Begizova I. Vzaimodejstvie muzyki i izobrazheniya $\mathrm{v}$ obraznoj strukture mul'tiplikacionnogo fil'ma [The interaction of music and images in the imagery of the animated film]: Avtoref. dis. ... kand. iskusstvoved: 17.00.03. Tbilisi: Tbilisskaya gos. konservatoriya imeni V. Saradzhishvili, 1985. 27 s. (in Russian)

2. Gvon Gyun Gzha. Hudozhestvenno-esteticheskaya specifika zvuka $\mathrm{v}$ animacionnom kino [Artistic and aesthetic specificity of sound in animated films]: Avtoref. dis. ... kand. iskusstvoved.: 17.00.03. Moscow: Vseros. gos. in-t kinematografii im. S. A. Gerasimova, 2005. 25 s. (in Russian)

3. Lissa Z. Estetika kinomuzyki [Aesthetics of film music]. Moscow: Muzyka, 1970. 495 s. (in Russian)

4. Shak T. Muzyka v strukture mediateksta. $\mathrm{Na}$ materiale hudozhestvennogo $\mathrm{i}$ animacionnogo kino [Music in the structure of the media text. On the material of feature and animated films]. St. Petersburg: Planeta muzyki, 2019. 384 s. (in Russian) 